\title{
Measurement of several qualitative traits and body size of Lombok Muscovy Ducks (Cairina moshcata) in semi-intensive rearing
}

\author{
M.H. Tamzil*, L. Lestari and B. Indarsih \\ Faculty of Animal Science, Mataram University, Jl. Majapahit No. 62, Mataram 83125, \\ West Nusa Tenggara Barat - Indonesia \\ *Corresponding E-mail: emhatamzil@yahoo.com \\ Received May 15, 2018; Accepted July 13, 2018
}

\begin{abstract}
ABSTRAK
Penelitian bertujuan untuk mengetahui karakteristik fenotipik entok Lombok menggunakan 100 ekor entok jantan dewasa dan 100 ekor entok betina dewasa. Lokasi penelitian ditentukan secara purposif random sampling berdasarkan populasi itik terbanyak. Penentuan peternak dan ternak yang akan dijadikan obyek pengamatan dilakukan secara insidental. Pengamatan dilakukan pada setiap individu ternak dengan mengamati warna, bobot badan dan ukuran bagian-bagian tubuh. Data ukuran tubuh ditabulasi dan dirata-ratakan kemudian dianalisis secara diskriptif, sedangkan warna bulu dihitung frekuensinya. Untuk mengetahui hubungan antara semua ukuran bagian tubuh pada bobot badan, data dianalisa menggunakan regresi sederhana. Hasil penelitian mendapatkan bahwa entok Lombok jantan mempunyai dua karakter bulu, yaitu warna putih dan hitam putih masing-masing dengan frequensi sama, sementara pada sex betina warna putih lebih dominan dibandingkan dengan warna hitam putih. Entok Lombok mempunyai 2 karakter warna paruh, yaitu: hitam dengan bagian tengahnya berwarna putih serta warna putih dengan warna ping di bagian tengahnya. Entok Lombok tergolong berukuran kecil, dengan ukuran badan yang jantan lebih besar dibandingkan dengan yang betina.
\end{abstract}

Kata Kunci: entok, fenotipik, ukuran badan, warna bulu

\begin{abstract}
The study was conducted to identify phenotypic characteristics of Lombok Muscovy ducks. A total of 100 adult male and 100 adult female Muscovy ducks. The research location was determined by purposive random sampling, while the determination of farmers and Muscovy ducks was done incidentally. Observations were made on each Muscovy duck by observing the color, body weight and size of body parts. The body size data were tabulated, averaged, and then analyzed descriptively; meanwhile, the plumage color data were calculated in frequency. To find the relation between size of body parts and body weight, data were analyzed using simple regression. The study found that the male Muscovy ducks had two plumage characteristics, consisting of white and black-white, both shared the same frequencies, while in the female Muscovy ducks, white color was more dominant compared to the black-white color. The colors of the beak were divided into two i.e., black with a white color in the middle and reddish-white with pink colors in the middle. The size of Lombok Muscovy ducks was rather small in comparison with the other Muscovy ducks. The size of male duck was larger than that of the female.
\end{abstract}

Keywords: body size, muscovy duck, phenotype characteristic, plumage color 


\section{INTRODUCTION}

Muscovy duck (Cairina moshcata) is the type of waterfowl that has long been developed by Indonesian as the source of meat and has shown a substantial contribution in supporting national food resilience. Muscovy duck grows evenly throughout the agricultural areas of Indonesia, including in the island of Lombok, where they are found from lowland to highland areas (Tamzil, 2017). The duck belongs to the genus of Cairina, Cairinini tribus, Anatidae family, and is believed to have originated from Central and South America, but is now found in almost all over the world, especially in the tropical zone (Down et al., 2017). In some Europe countries, the ducks were developed as meat-producing poultry (Marie-Etancelin et al., 2008; Drouilhet et al., 2014). In Lombok island, the ducks were reared by small farmers with semi-intensive rearing system, in which during the night the ducks are kept in a simple house, while during the day they were freed to roam around the yard of the farmers, with just enough an additional feeding (Tamzil, 2018). This handling shows that the ducks in Lombok grows naturally, without any efforts to maximize its genetic potential. Nevertheless, the ducks play a considerable contribution as a commodity supporting familyfood security, especially for religious and social purposes (Tamzil, 2018).

The development of a germ plasma for various purposes, such as for conservation and/or for food production, needs to begin with the collection of basic data on the phenotypic characteristics, like physical characteristics, body size, color (plumage and skin), and head shape (Khan et al., 2008). The phenotypic diversity in a population was the product of the interaction among evolutionary forces, such as selection, migration, mutation, maintenance management, and environmental stress experienced by an individual over the years; such diversity in a population can be used as a guide to select bird for multiple purposes (Oguntunji, 2013).

Unlike the Indian Runner ducks, which are widely developed as egg producers, Lombok Muscovy ducks as one of the germ plasma of meat sources has not been studied intensively. Therefore, this study acts as a pioneer study aiming to collect phenotypic data which can be utilized as a selection basis to enhance Lombok Muscovy ducks role as meat-producing poultry.

\section{MATERIALS AND METHODS}

Observations on the color characteristics of the plumages and the size of the body were conducted by performing a direct examination on 100 adult male and female Muscovy ducks that were semi-intensive rearing applied by farmers. Purposive random sampling was assigned based on the districts with the highest duck population out of 5 districts in Lombok Island, East Lombok district was chosen as sampling location as it has the highest duck population, whereas the determination of the farmers and the ducks to be used as observation objects was done incidentally i.e., ducks found by chance in various regions (Nurhayati, 2012). The observations were made to an individual duck by examining the phenotype characteristic data, such as plumage color, beak color, and shank color. The data of body weight were obtained by weighing individual birds with a $5 \mathrm{~kg}$ digital balance to the nearest of $0.1 \mathrm{~g}$ accuracy. The neck length, back length, upper thigh length, drumstick length, tarsometatarsus length were measured with the aid of a tape rule. Whilst, wing length, head circumference, chest circumference, and tarsometatarsus circumference were measured with the aid of a yarn as a help tool. The yarn measurement was next metered using tape measure. Chest depth and width were measured using a slide range. The measurement procedure is presented in Figure 1.

1. Head circumference was measured by circling the yarn from the mandibular bone to the temporan bone.

2. Neck length was measured the distance between the first cervical vertebra and the last cervical vertebra.

3. Wing length was measured the distance between the base of humerus bone and the tip of finger bones.

4. Back length was measured the distance between the last cervical vertebra bone and the vertebrae caudales bone.

5. Chest circumference was measured by circling the yarn from back to chest. The yarn was then metered using a tape measure.

6. Chest width was measured the distance between the right side of the chest and the left side of the chest.

7. Chest depth was measured the distance between upper and lower sternum

8. The upper thigh (femur) length was measured the distance between the base 
and the tip of the thigh (femur) bone.

9. The drumstick length was measured the distance between the base and the tip of tibia bone.

10. Tarsometatarsus length was measured the distance between the base and the tip of tarsometatarsus bone.

11. Tarsometatarsus circumference was measured by circling yarn on tarsometatarsus. The yarn was then measured using tape measure.

The body size data were tabulated, averaged, and analyzed descriptively, while the data of plumage color was calculated its frequency using the
Stanfield formula (1991). The relation between size of body parts and body weight was analyzed using simple regression.

\section{RESULTS AND DISCUSSION}

Data of the color characteristic are presented in Table 1. It was found that the male Muscovy ducks had two plumage characteristics, namely white and black-white (black with white spots). Both characteristics shared the same frequencies. Meanwhile, on the female ducks, the frequency of white color was higher than that of black-white (white spots). The images of the two color

Table 1. Color Characteristics of Adult Lombok Muscovy Ducks

\begin{tabular}{|c|c|c|c|}
\hline \multirow{2}{*}{ Body parts } & \multirow{2}{*}{ Plumage color } & \multicolumn{2}{|c|}{ Sex } \\
\hline & & Male $(n=100)$ & Female $(n=100)$ \\
\hline \multirow[t]{4}{*}{ Body } & Black white & 50 & 38 \\
\hline & White & 50 & 62 \\
\hline & White black & 0 & 0 \\
\hline & Brownish-white black & 0 & 0 \\
\hline \multirow[t]{4}{*}{ Back } & Black white & 18 & 0 \\
\hline & White & 50 & 52 \\
\hline & White black & 0 & 0 \\
\hline & Brownish-white black & 32 & 48 \\
\hline \multirow[t]{4}{*}{ Wing } & Black white & 40 & 30 \\
\hline & White & 50 & 52 \\
\hline & White black & 0 & 0 \\
\hline & Brownish-white black & 10 & 18 \\
\hline \multirow[t]{4}{*}{ Chest } & Black white & 42 & 34 \\
\hline & White & 50 & 52 \\
\hline & White black & 8 & 14 \\
\hline & Brownish-white black & 0 & 0 \\
\hline \multirow[t]{2}{*}{ Beak } & $\begin{array}{l}\text { Black at the base and the tip with white colors in } \\
\text { the middle }\end{array}$ & 50 & 40 \\
\hline & Reddish-white with pink colors in the middle & 50 & 60 \\
\hline \multirow[t]{3}{*}{ Shank } & Black & 21 & 22 \\
\hline & Black with yellowish foot web & 30 & 30 \\
\hline & Yellow & 49 & 48 \\
\hline \multirow[t]{5}{*}{ Skin } & White & 34 & 38 \\
\hline & Reddish-white & 40 & 50 \\
\hline & Yellowish-white & 20 & 0 \\
\hline & Yellowish-red & 6 & 0 \\
\hline & Yellow & 0 & 12 \\
\hline
\end{tabular}


characters are shown in Figure 2. Back and wings of the ducks having black-white plumages were dominated by white color, while on the chest, for the female ducks were dominated by white color, and for the male ducks were dominated by blackwhite (white spots). The plumage colors obtained in this study were different from the colors of Nigerian Muscovy ducks (Oguntunji and Ayorinde, 2015; Oguntunji and Ayorinde, 2014). Oguntunji and Ayorinde (2015) reported that out of 1020 Muscovy ducks used in their study, in which they were found in various agricultural areas, it was observed that black-white (white spots) color was the highest frequency found, followed by black, white, white-brownish, and blue colors with frequency of 45, 34, 10, 9.71, and 0.39 , respectively. A study by Raji et al. (2009) and Chia and Momoh (2012) revealed that one third of the Muscovy Ducks observed had white color.

The beaks of Lombok Muscovy Ducks (males and females) had two color patterns, which were black color with a white color in the center and white color with a black color in the center. On the female ducks, the frequency of white beak with a black color in the center was higher than that of black beak with a white color in the center. However, on the male ducks, both patterns shared the same frequency. The beak colors are shown in Figure 3.

As indicated in Table 1 that the shanks of male and female Lombok Muscovy ducks had three different color characteristics i.e., black, black with the yellowish-white foot web, and plain yellow. The yellow shank frequency was the highest followed by the black with the yellowishwhite foot web, and plain yellow, respectively. Muscovy ducks having white feathers were usually appeared with yellow shanks. However, Muscovy ducks having black feather with a white in the middle had both plain black shank and yellowish-white foot web. The high frequency of yellow shank was caused by the facts that all Muscovy ducks with white feathers had yellow

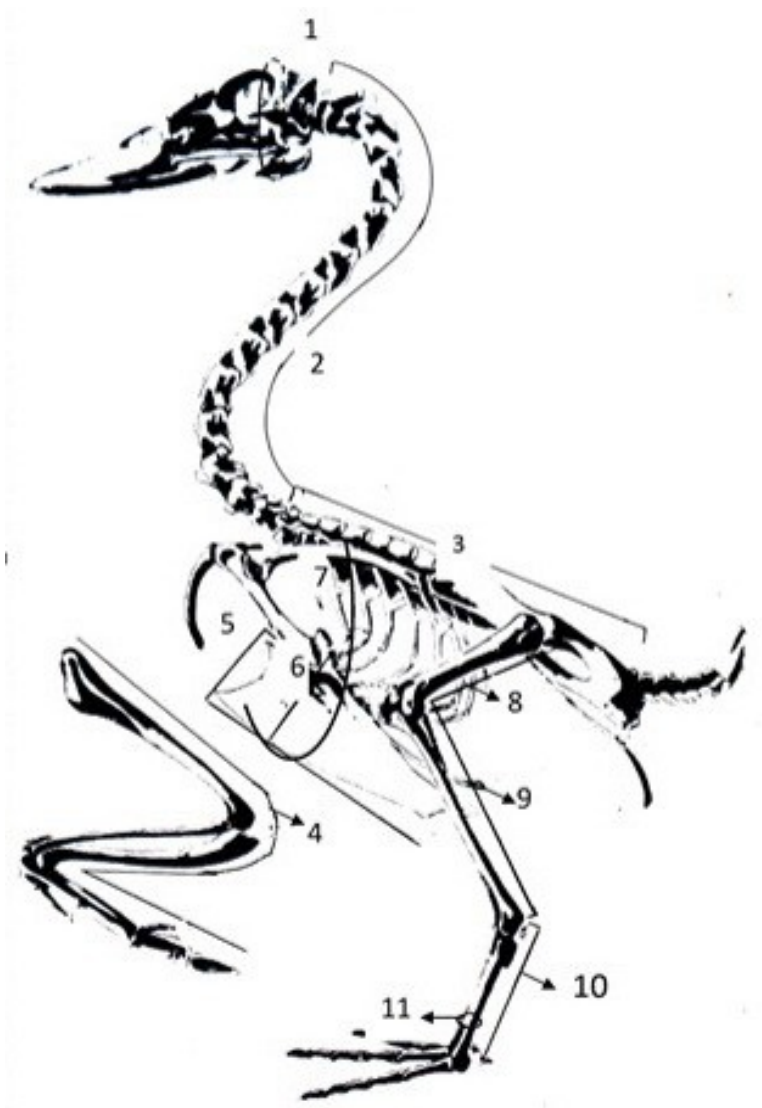

Figure 1. Body part measurements of Muscovy ducks adopted from duck skeleton (Srigandono, 1986). Measurement procedure of $1=$ Head circumference, $2=$ Neck length, $3=$ Wing length, $4=$ Back length, $5=$ Chest width, $6=$ Chest depth, $7=$ Chest circumference, $8=$ Upper thigh (femur) length, $9=$ Drumstick length, $10=$ Tarsometatarsus length, 11. Tarsometatarsus circumference 

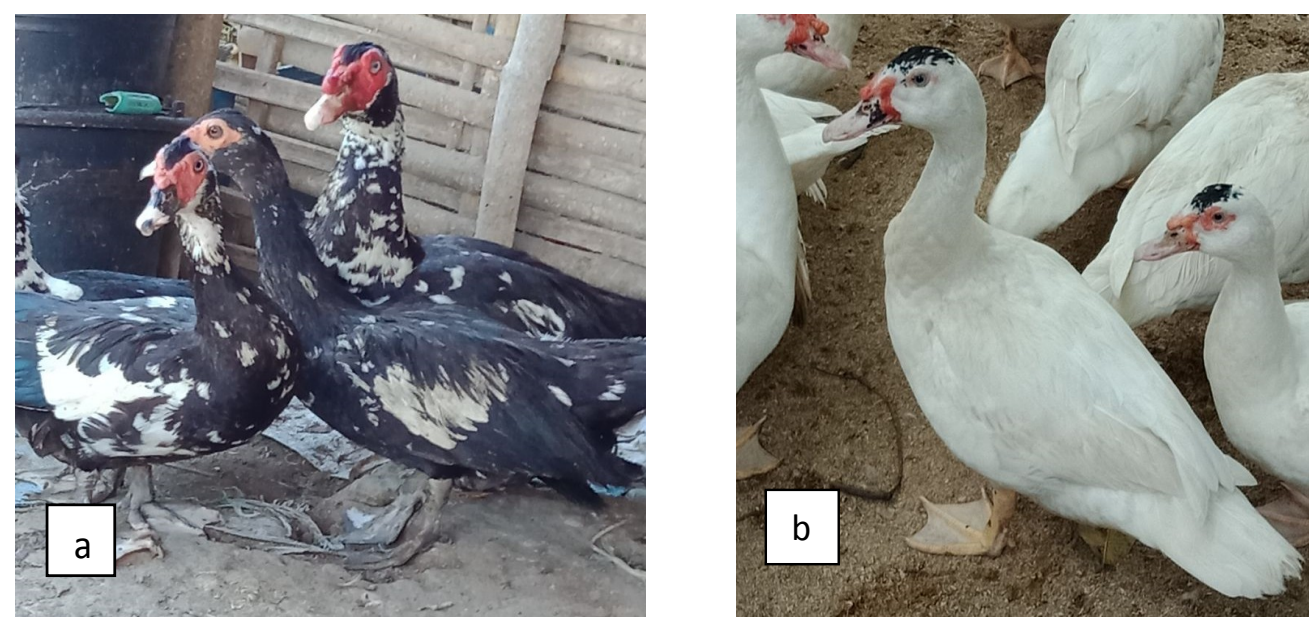

Figure 2: Plumage color. A: black, b: white
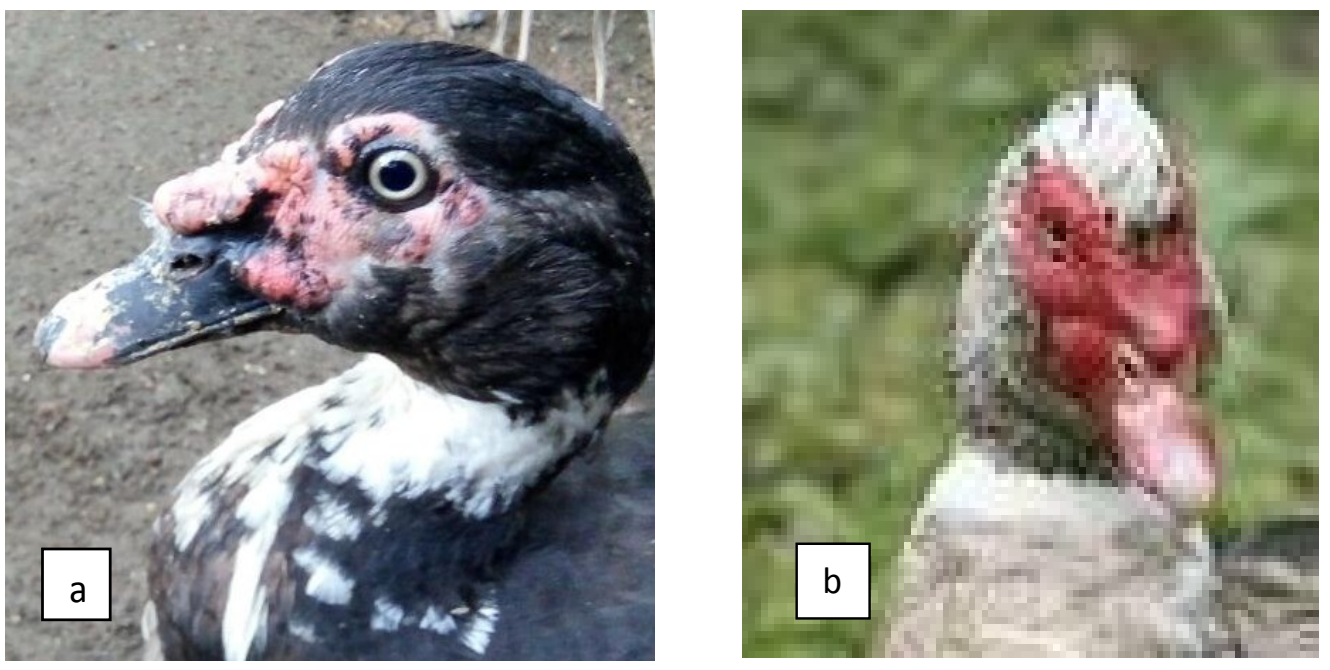

Figure 3. Beak color. $\mathrm{a}=$ Black at the base and the tip with white colors in the middle; $\mathrm{b}=$ Reddishwhite with pink colors in the middle

shank. On the other hand, not all Muscovy ducks having black feathers had black shank; some with yellow shanks were found.

The data in Table 1 show that the shank of the ducks has three shank color characteristics, i.e. black with yellowish foot web, and yellow (Figure 4). The most dominant shank color was yellow, followed by black with yellowish foot web and black respectively. This shows that the color of yellow was more dominant compared to black on Lombok Muscovy ducks.

Skin colors of Lombok Muscovy ducks (male and female) were dominated by reddishwhite color. The skin colors of the male varied than those of the female Muscovy ducks. In the male ducks, there were four skin color variations i.e., the reddish-white color with the highest frequency, followed by white, yellowish-white, and red-yellowish colors, respectively. Mean while, in the female ducks, the highest skin color frequency was shown by reddish-white followed by white and yellow colors.

The diversity of skin color in Lombok Muscovy ducks found in this study was higher 
than those found in the previous studies. A study conducted by FAO (2009a) in Indonesia and Cambodia only identified Muscovy ducks having white skin. While in Egypt (FAO, 2009b), in addition to the white skin color, the yellow skin color was also identified even though with the lower frequency $(11.54 \%)$.

There is a possibility that the white color reported by FAO (2009a) includes the reddishwhite color identified in this study. The same possibility was also applied for the yellow color reported by FAO (2009b), in which the yellow color already covers yellowish-white and yellowish-red colors found in this study. The skin color was determined by xanthophyl and melanin and the combined effects of the two factors result in a phenotypic variation (Mancha et al., 2006a). Yellow skin color was affected by the amount of carotenoids, especially xanthophyl in the diet (Oguntonji and Ayorinde, 2014a).

Data in Table 2 also revealed that the body size of male Muscovy ducks was relatively bigger than that of the female. This phenomenon caused by gender differences is a common case that is almost applicable to some types of ducks, such as Pekin duck, imported and local ducks (Brahmantiyo et al., 2014), Central Java Muscovy ducks (Fatmarischa et al., 2013), Nigerian chickens (Daikwo et al., 2011), and Papua chickens (Mu'in et al., 2010). Ogah and Ari
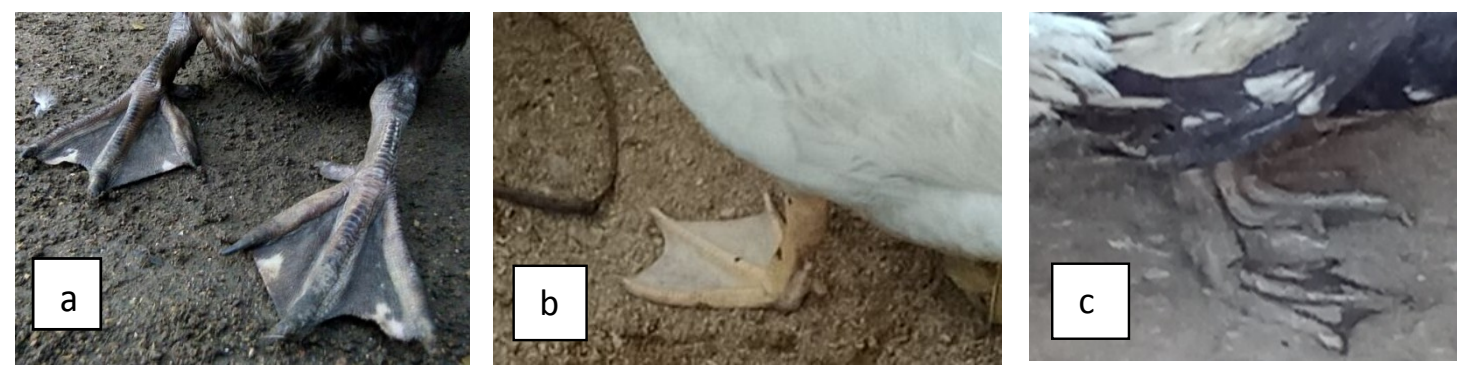

Figure 4. Shank color. $\mathrm{a}=$ black with yellowish foot web; $\mathrm{b}=$ yellow; $\mathrm{c}=$ black

Table 2. The Size of Adult Lombok Muscovy Ducks (Mean \pm SD)

\begin{tabular}{lrc}
\hline \multirow{2}{*}{ Body Weight and Body Part } & \multicolumn{2}{c}{ Sex } \\
\cline { 2 - 3 } & Male $(\mathrm{n}=100)$ & Female $(\mathrm{n}=100)$ \\
\hline Body weight $(\mathrm{g})$ & $3622 \pm 342.41$ & $2493 \pm 413.70$ \\
Head circumference $(\mathrm{cm})$ & $16.37 \pm 0.31$ & $14.08 \pm 0.12$ \\
Beak length $(\mathrm{cm})$ & $4.13 \pm 0.11$ & $4.1 \pm 0.12$ \\
Neck length $(\mathrm{cm})$ & $18.32 \pm 0.98$ & $14.87 \pm 0.34$ \\
Chest width (cm) & $20.32 \pm 0.93$ & $16.19 \pm 0.42$ \\
Chest depth (cm) & $10.27 \pm 0.81$ & $10.10 \pm 0.42$ \\
Chest circumference (cm) & $40.39 \pm 0.74$ & $35.92 \pm 0.81$ \\
Back length (cm) & $36.30 \pm 0.93$ & $20.63 \pm 0.45$ \\
Wing length (cm) & $82.81 \pm 0.62$ & $61.19 \pm 0.44$ \\
Thigh length (cm) & $7.59 \pm 0.51$ & $5.92 \pm 0.33$ \\
Drumstick length (cm) & $7.03 \pm 0.55$ & $7.82 \pm 0.41$ \\
Tarsometatarsus length $(\mathrm{cm})$ & $6.90 \pm 0.41$ & $5.05 \pm 0.24$ \\
Tarsometatarsus circumference $(\mathrm{cm})$ & $5.74 \pm 0.49$ & $4.13 \pm 0.24$ \\
\hline
\end{tabular}


(2012) and Ogah et al. (2011) explicitly state that the body size of male Muscovy ducks is larger than that of female Muscovy ducks.

This study also found that the body weights of Lombok Muscovy ducks were lower than the body weights of Muscovy ducks from other regions. The average body weights of France Muscovy ducks aged 49 days reaches $3.054 \mathrm{~kg}$ (Drouilhet et al., 2014). Huang et al. (2012) reported that the weight of adult male Muscovy ducks is $4.6-6.8 \mathrm{~kg}$, while the weight of the adult female is $2.7-3.6 \mathrm{~kg}$. Other studies report that body weights of male and female ducks at the age of 12 weeks reach the levels of 5.383 and 2.874 $\mathrm{kg}$, respectively (Kleczek et al., 2007). However, in this study the body weights of the adult male ducks only reached $3.62 \mathrm{~kg}$ and $2.49 \mathrm{~kg}$ for the adult female ducks. Based on the present study, only Central Java (Demak, Magelang, and Pekalongan) Muscovy ducks exhibiting lower body weights than Lombok Muscovy ducks (Fatmarischa et al., 2013). Some factors contributing to the low body weights of the Lombok Muscovy ducks in this study were the fact that the ducks were grown by small farmers in semi-intensive rearing system, in which during the day the ducks were freed to roam around the yard with just enough additional feeding, while during the night they were kept in a simple cage. Feeds given to the ducks include rice waste, rice bran, coconut pulp, and vegetable waste such as spinach, water spinach, papaya leaves, and banana leaves. Farmers obtained ducklings by breeding the ducks themselves, since superior duck breeds are not available, different from breeds of broiler chicken and laying hens (Tamzil, 2018). Therefore, improving the growth of Lombok Muscovy ducks, genetic improvement through selection approaches, cross breeding, bringing in superior breeds, and or improving breeding system are suggested. From the results of this study, it can be concluded that the Lombok Muscovy ducks belong to the small body size type.

The small body size of Lombok Muscovy duck is also reflected on the sizes of the chest width, chest circumference, back length, wingspan, and upper thigh length. Juhari et al. (2013) reports that body length of adult female is $25.181 \mathrm{~cm}$, while Teguia et al. (2008) revealed that body length of female ducks at the age of 6 weeks reached $39.65 \mathrm{~cm}$, with a relatively equal chest circumference. The chest area of ducks where the highest meat deposition is found, followed by the thigh area (Tamzil et al., 2015). The increase in body size in those body parts can be used as an indicator of the ability of a duck as a meat producer (Ismoyowati et al., 2006). Another benefit of chest length and chest circumference is they can be used as a morphological variable identifier of Muscovy duck, Mule duck and Indian Runner duck (Johari et al., 2013).

The data in Table 2 also shows that the length of upper thighs and lower thighs of the female ducks in this study was shorter than those of identified by Johari et al. (2013) who measured the length of the upper thigh and lower thigh of female Muscovy ducks was $7.299 \mathrm{~cm}$ and $9.673 \mathrm{~cm}$ respectively. This size was almost the same as the length of upper thigh and lower thigh of local male ducks in the present study.

The wing lengths obtained in this study were quite high compared to the wing lengths identified by other studies. Reported by Johari et al. (2013), it was found that the wing length of Central Java ducks was $13.30 \%$ shorter than the wing length of Lombok female ducks. Result of this study showed that the weight of Lombok Muscovy ducks is lower than that of other ducks from the other regions but has a relatively longer wing size. This is an indication that Lombok Muscovy ducks still have the character of liking to fly. A long wing length of birds support the flight speed, as it can pick up more wind impulses when the wings are flapping (Duezler et al., 2006).

Table 3 shows the correlation between the parameters of body size of Lombok Muscovy ducks and the body weight. Among all of measured body size parameters, it appeared that the most dominant body sizes affecting body weight were wing length and chest size (width, depth, and circumference), followed by the back length and head circumference. The contributions of the other body parts were not significant. The high contribution of chest size to body weight is due to the fact that the chest is the body component where the highest meat deposition takes place. This highest contribution of chest area is followed by the thigh area. The increase of back size also affected body weight directly due to the dominant bone component in the back area (Tamzil et al., 2015).

The wing length contributes positively to the body weight of male $(r=0.81)$ and female $(r=$ 0.80) Muscovy ducks. Brahmantiyo et al. (2014) reported a larger $\mathrm{r}$ value of 0.855 in imported ducks and 0.88 in local ducks. Given the big contribution of wing length on the body weight of 
Table 3. Correlation Between Some Size of Body Parts and Body Weight of Muscovy Ducks

\begin{tabular}{lcc}
\hline \multirow{2}{*}{\multicolumn{1}{c}{ Body Parts }} & \multicolumn{2}{c}{ Correlation Value $(\mathrm{r})$} \\
\cline { 2 - 3 } & Female & Male \\
\hline Head circumference & 0.59 & 0.24 \\
Neck length & 0.34 & 0.12 \\
Chest width & 0.62 & 0.64 \\
Chest depth & 0.64 & 0.75 \\
Chest circumference & 0.79 & 0.67 \\
Back length & 0.71 & 0.63 \\
Wing length & 0.80 & 0.81 \\
Thigh length & 0.42 & 0.69 \\
Drumstick length & -0.08 & 063 \\
Tarsometatarsus length & 0.48 & -0.21 \\
Tarsometatarsus circumference & 0.48 & -0.01 \\
\hline
\end{tabular}

ducks, some researchers defined the wing length as a differentiating factor (Muzani et al., 2010; Yakubu, 2011; Fatmarischa et al., 2013).

The drumstick length of Lombok Muscovy duck (Table 2) is relatively similar compared to the results reported by Johari et al. (2013), but they are shorter than those reported by Fatmarischa et al. (2013) in Central Java Muscovy ducks. Qualitative properties such as the lengths of thigh, and tarsometatarsus, as well as the circumference of tarsometatarsus, the length of the third finger, wings, and beak can be used as morphological determinants of birds as well as predictors of body conformation and body weight (Muzani et al., 2010; Oguntunji and Ayorinde, 2014). Physical diversities of ducks were due to the differences in body sizes and shapes (Ogah and Ari, 2012; Ogah et al., 2011). Shank length is a good indicator to determine weight since shank length correlates positively with body weight; however legs that are too long are not desirable because short legs are better to support the body since they are stronger (Oguntunji and Ayorinde, 2014).

\section{CONCLUSION}

The study concludes that Lombok Muscovy ducks have two plumage-colored characters, white and black-white colors. Skin color of the duck was dominated by reddish-white color, whereas the beak consisted of two color characters, namely black with white colors in the middle and white with pink colors in the middle. Lombok Muscovy ducks is the type of small sexual dimorphism ducks.

\section{ACKNOWLEDGEMENTS}

Authors would like to thank and appreciate to Prof. Wasmen Manalu, Ph.D., Professor at the Faculty of Veterinary Medicine, Bogor Agricultural University, for his willingness to read and correct this manuscript.

\section{REFERENCES}

Brahmantiyo, B., R H. Mulyono dan A. Sutisna. 2014. Ukuran dan bentuk itik Pekin (Anas platyrhynchos), entok impor dan Entok lokal (Cairina moschata). JITV 19 (3): 266-273.

Chia, S.S. and O. Momoh. 2012. Some physical and reproductive characteristics of Muscovy ducks (Cairina moschata) under free range management system in two locations in Benue State of Nigeria. In Proceedings 37th Annual Conference of Nigerian Society for Animal Production. pp. 20-22.

Daikwo, I.S., A.A. Okpe and J.O. Ocheja. 2011. Phenotypic characterization of local chickens in Dekina. Int. J. Poult. Sci. 10: 444-447. 
Down, J., R. Loraamm, J.H. Anderson Jr., J. Perry and J. Bullock. 2017. Habitat use behaviours introduced Muscovy Duck (Cairina moschata) in urban and suburban environments. Suburban Sustainability. 5:110.

Drouilhet, L., B. Basso, M.D. Bernadet, A. Cornuez, L. Bodin, I. David, H. Gilbert and C. Marie-Etancelin. 2014. Improving residual feed intake of mule progeny of Muscovy ducks: Genetic parameters and responses to selection with emphasis on carcass composition and fatty liver quality. J. Anim. Sci. 92:4287-4296

Duezler, A., O. Ozgel and N. Dursun. 2006. Morphometric analysis of the sternum in avian species. Turk. J. Vet. Anim. Sci. 30:311-314

FAO (Food and Agricultural Organization). 2009a. Characterization of domestic duck production systems in Cambodia. Prepared by M.T. Dinesh, E. Geerlings, J. Sölkner, S. Thea, O. Thieme and M. Wurzinger. AHBL Promoting strategies for prevention and control of HPAI. Rome.

FAO (Food and Agricultural Organization). 2009b. Characterization of domestic chicken and duck production systems in Egypt. Prepared by Haitham M. Yakout, M. Kosba and O. Thieme. AHBL-Promoting strategies for prevention and control of HPAI. Rome.

Fatmarischa, N., Sutopo , and S. Johari. 2013. Ukuran tubuh entok di tiga kabupaten Provinsi Jawa Tengah. Sains Peternakan. 11 (2):1-7.

Huang, J.F., H. Pingel, G. Guy, Lukaszewicz, E, Baeza, S.D. and S.D. Wang. 2012. A Century of progress in waterfowl production, and a history of the WPSA water fowl working group. World's. Poult. Sci. J. 68:551-563.

Ismoyowati, T. Yuwanta, J. P. Sidadolog dan S. Keman. 2006. Hubungan antara karakteristik morfologi dan performans reproduksi itik Tegal sebagai dasar seleksi. J. Indonesian Trop. Anim. Agric. 31:152-156.

Johari, S., N.D. Kususmadani, dan E. Kurnianto. 2013. Multivariate of the morphological traits of female duck, muscovy duck and mule duck. J. Indonesian Trop. Anim. Agric. 38(2):143-148.

Khan, M.S., M.A. Khan, and S. Mahmood. 2008. Genetic resources and diversity in Pakistan goats. Int. J. Agric. Biol. 10(2): 227-231.

Kleczek, K., E. Wilkiewicz-Wawro, K. Wawro and W. Makowski. 2007. Effect of body weights of day-old Muscovy ducklings on growths and carcass traits. Arch. Tierz., Dummerstorf. 50 (2):204-213

Mancha, Y.P., S.T. Mbap and S.D. Abdul. 2006a. Incidence and frequencies of some qualitative traits in the local chicken population on the Jos Plateau. Trop. J. Anim. Sci. 9(1):3-46.

Mancha, Y.P., S.T. Mbap and S.D. Abdul. 2006b. Phenotypic characterization of local chickens in the northern region of Jos Plateau. Trop. J. Anim. Sci. 9(1):47-55.

Marie-Etancelin C., H. Chapuis, J.M. Brun, C. Larzul, M.M. Mialon-Richard and R. Rouvier. 2008. Genetics and selection of mule Duck in France: a review. World's Poult. Sci. J. 64:187-206.

Mu'in, M.A., Supriyantono dan H.T. Uhi. 2010. Polimorfisme gen Insulin-like growth factorI (IGF-I) dan efeknya terhadap pertumbuhan ayam lokal. JITV. 14 (4): 288-294.

Muzani, A., B. Brahmantiyo, C. Sumantri, A. Tepyadi. 2010. Pendugaan jarak genetic pada itik Cihateup, Cirebon dan Mojosari. Media Peternakan. 109-116.

Nurhayati, S. 2012. Metode Penelitian Praktis. Edisi ke-2. Penerbit Usaha Nasional, Pekalongan.

Ogah, D.M. And M.M. Ari. 2012. Evaluating inbreeding rate in population of local Muscovy duck. Egypt. J. Poult. Sci. 32(1):217-220.

Ogah, D.M., M.O. Momoh and N.I. Dim. 2011. Application of canonical discriminant analysis for assessment of genetic variation in Muscovy duck ecotypes in Nigeria. Egypt. Poult. Sci. 31(11):429-436.

Oguntunji, A.O. 2013. Phenotypic and biochemical characterization of the Nigerian Muscovy ducks. Bowen University, Iwo, Osun State, Nigeria. pp. 371 (PhD Dissertation).

Oguntunji, A.O. and K.L. Ayorinde. 2015. Phenotypic characterization of the Nigerian Muscovy ducks (Cairina moschata). Anim. Genet. Resources. 56:37-45

Oguntunji, A.O. and K.L. Ayorinde. 2014. Multivariate analysis of morphological traits of the Nigerian Muscovy ducks (Cairina moschata). Arch. Zootec. 63(243):483-493.

Raji, O., J.U. Igwebuike and M.T. Usman. 2009. Zoometrical body measurements and their relation with live weight in matured local 
Muscovy ducks in Borno State, Nigeria. J. Agric. Biol. Sci. 4(3):58-62.

Srigandono, B. 1986. Ilmu Unggas Air. Gadjah Mada University Press, Jogjakarta.

Stansfield, W.D. 1991. Theory and Problems of Genetics. Third Edition. McGraw-Hill Book Company Inc., New York.

Tamzil, M.H. 2018. Pola pemeliharaan ternak entok: Studi kasus pada Kelompok Peternak itik Bagek Nyake Lombok Timun. Jurnal Ilmu dan Teknologi Peternakan Indonesia. (In Press).

Tamzil, M.H., M. Ichsan, N.S. Jaya, M. Taqiuddin. 2015. Growth rate, carcass weight and percentage weight of carcass parts of laying-type cockerels, kampong chicken and arabic chicken in different ages. Pak. Jour. Nutr. 14(7): 377-382.

Tamzil, M.H. 2017. Ilmu dan Teknologi Pengelolaan Plasma Nutfah Ternak Itik. Mataram University Press. Mataram.

Téguia, A., H. M. Ngandjou, H. Defang, J. Tchoumboue. 2008. Study of the live body weight and body characteristics of the African Muscovy duck (Cairina moschata). Trop. Anim. Health. Prod. 40:5-10

Yakubu, A.2011. Discriminant analysis of sexual dimorphism in morphological traits of African Muscovy ducks. Archivos De.Zootecnia. 60(232):1-8. 